\title{
The effect of distribution supply fertilizer on rice production improvement in Gorontalo City
}

\author{
Amir Halid; Heldy Vanni Alam; Mohamad Hamdi H. Payuyu \\ Agribusiness Study Department, Post Graduated Program, Universitas Negeri Gorontalo, \\ Indonesia \\ e-mail correspondence: amirhalid_ung@yahoo.com
}

\begin{abstract}
The purposes of this research are to: 1) analyze the distribution of subsidized fertilizer in Gorontalo City, 2) analyze the distribution of subsidized fertilizers partially (right price, right amount, and time) to increase rice production in Gorontalo City. The study conducted in Gorontalo City with a sample number of 95 farmers. The research method used is survey method. Data analysis used is multiple linear regression analysis. The results showed that there are two distributors fertilizer in Gorontalo City is PT. Indonesian Trade Company (PT PPI) and Indonesian Trade Cooperative (KPI), and 5 authorized retailers which are distributing subsidized fertilizer is Kios Tani Lestari, Anugerah Tani Kios, Saprodi Tani Kios, Cahaya Tani Kios and Bunga Tani Kios. PT. PPI is responsible for distributing NPK, SP36 and ZA fertilizers while KPI is responsible for the distribution of Urea fertilizer. Distribution of subsidized fertilizer on rice farming simultaneously have a positive and real effect on increasing rice production, while partially that have positive and real influence that is Right price, Right amount and time to increase rice production.
\end{abstract}

Keywords: Distribution, Subsidized fertilizer, Production, Rice farming

\section{INTRODUCTION}

One of the government effort is to improve the productivity and quality of food commodities is through the application of cultivation technology appropriately with the use of production facilities. Therefore, to support these efforts, the government plays a role in the agricultural development program. To illustrate the role of government, the government can develop policies that can facilitate the entry of investment into the region (such as investment in the agricultural sector), creating a concise bureaucracy and even directly involved in economic activities through infrastructure and infrastructure development in various sectors. One example of government policy in 2008 related to agricultural sector investment is the subsidy given to farming production facilities, especially fertilizer (Khairunisya, 2009).

Fertilizer has always been on the front line in an effort to increase world food production and possibly more than any other type of input, widely responsible for the success it has achieved. Fertilizer is also one of the important production factors for farmers. The existence of fertilizer properly in terms of quantity, type, quality, price, place and time will determine the quality and quantity of agricultural products produced. Fertilizer as a chemical or organic material acts as a provider of nutrients for plant purposes directly or indirectly. Subsidized fertilizer is one of the means of production which is available to be subsidized by the government for farmers, including farmers 
whose needs per sub-sector and Highest Retail Price (HET) is regulated by Minister of Agriculture Regulation no. 69 / Permentan / SR.310 / 12/2016.

Gorontalo Province is one of rice / rice producing areas. Therefore, fertilizer is one of the most decisive production facilities for increasing agricultural production, especially rice. Based on Gorontalo Province Agricultural Data Base in 2016 the area of wetland in Gorontalo Province is 33,223.9 ha and each year produce 307,041 tons of rice. If the conversion to rice is 186,223 tons. The city of Gorontalo is the only city in Gorontalo province that owns paddy fields. Although every year the rice fields in Gorontalo City are degraded due to land conversion but still contributes to rice production in Gorontalo Province (Dispan Gorontalo Province, 2017).

Subsidized fertilizer is not kind of goods that are not sold freely by the Government and their use is always monitored. Subsidized fertilizer demand in Gorontalo Province 2017 based on Regulation of the Minister of Agriculture No. 69 / Permentan / SR.310 / 12/2016 on Requirement and Highest Retail Price of Subsidized Fertilizer for Agriculture sector followed by Head of Gorontalo Provincial Agricultural Service Decree number 821 / SK / 902 / PTPH-PSP / XII / 2016 concerning Allocation of Subsidized Fertilizer Requirement in Regency / Municipality Region of Gorontalo Province are: Urea: 24.750ton, SP36998 ton, ZA 273 ton, NPK 24,013ton and Organic 353 ton (Agriculture Government Gorontalo Province, 2017).

The allocation of subsidized fertilizer for Gorontalo City for the last three years start from 2014-2016 based on the Decree of Head of Department of Marine, Fishery and Agriculture of Gorontalo City, namely 2014 subsidized allocation for Urea fertilizer 550 tons, SP36 fertilizer 80 tons, ZA fertilizer 40 ton, NPK fertilizer equal to 669 ton, and organic fertilizer equal to 124 ton. In 2015 the allocation of subsidized fertilizer for Urea fertilizer is 449,88 ton, SP36 fertilizer equal to 110 ton, ZA fertilizer equal to 40 ton, NPK fertilizer equal to 556,09 ton, organic fertilizer equal to 149,91 ton. And in 2016 the allocation of subsidized fertilizer for Urea fertilizer is 62 tons, SP36 fertilizer is 47 tons, ZA fertilizer is 4 tons, NPK fertilizer is 668 tons, and organic fertilizer is 18 tons (DKPP of Gorontalo city, 2017).

The condition of rice production in sub district located in Gorontalo city in 2015 is 10,886 tons with the land area of 476.9 ha, West Kota District as much as 505 tons with a land area of 34 ha, East Kota District with 1,862 tons with wide area land area of 108.6 ha, Kota Tengah sub-district of $1,858.79$ tons with a land area of 73.6 ha, South City District of 30 tons with a land area of 1.69 ha, in Hulontalangi and Dumbo Raya subdistricts there is no rice production because this sub-district does not have paddy field for cultivation, Dungingi District rice production reaches 484 ton with area of land equal to 41,5 ha, and Sipatana District 4,294,08 ton with wide of land equal to 122,6 ha. Production of wetland rice in 2016 for North Kota District reached 7,765.56 tons with a land area of 471.8 ha, West Kota District of 588.2 tons with a land area of 25.5 ha, East Kota District of 1,765.8 tons with total area of 105.9 ha, Kota Tengah sub-district reached 960.52 tons with a land area of 72.9 ha, South Kota District of 19.2 tons with a land area of 1.53 ha, Dungingi sub-district of 543.84 tons total area of 27.5 ha, and the production of Sipatana Sub-district reached 1,864.68 tons with a land area of 119.8 ha (DKPP of Gorontalo City, 2017).

From the background above, the objectives of this research are 1) to analyze the distribution of subsidized fertilizer in Gorontalo city, 2) to analyze the distribution of subsidized fertilizer (Right price, Right quantity, and time) to increase rice production in Gorontalo City. 
Distribution is the efforts made by producers and marketing agencies to ensure the availability of products for the target market in the time required. Furthermore the distribution is a set of intermediaries that are closely linked with one another in the activities of channeling products to consumers (buyers) (Suharno, 2008).

Distribution is a group of organizations that make a process of distribution activities of goods or services ready for use or in consumption by consumers (buyers). Furthermore, distribution is a set of institutions that are interconnected with each other to conduct activities of distribution of goods or services so that they are available for use by consumers (buyers) (Alma, 2007).

Winardi (2005) stated that distribution channel is an intermediate group that is closely related to each other and which distributes the products to the buyer. Distribution channels are essentially intermediaries that bridge between producers and consumers. These intermediaries can be categorized into two groups: intermediary traders and intermediary agents. The difference lies in the ownership aspect and the process of negotiation in the transfer of the distributed products: 1) Intermediary trader. The merchant middleman is responsible for the ownership of all goods that are marketed or, in other words, the trader has the right to own the goods. There are two groups that belong to the intermediary traders, namely: large goods traders and retailers; 2) Intermediary agent. These middleman agents have no property rights over all the goods they handle. They can be classified into two groups, namely: 1) Supporting Agent, that is buying and selling agents, transport agent and storage Agent; 2) Complementary agents, that is agents assisting in the financial field, agencies that assist in the field of decisions, agents who can provide information and special Agent

Subsidies are government payments to domestic producers. Cash, low interest loans, tax deductions, and government participation in domestic firms. The main benefit gained for domestic producers is that their international competitive value is increasing. Subsidies may be aimed at: (1) production subsidies, in which the government closes some of its production costs to encourage increased output of certain products, (2) export subsidies, given to export products deemed to be helpful to the country's trade balance; is given to pay part of the company's wage expenses in order to be absorbed more jobs and reduce unemployment, and (4) income subsidies, provided through the government's transfer payment system to raise the minimum standard of living for certain groups such as old-age and other benefits (Rini, 2006).

Production theory is used to see the relationship between input (production factor) and output (production). Production theory is expected to explain the occurrence of a production process and can predict what will happen. The end result of a production process is the product or output. Products or production in agriculture or other fields may vary which, among other things, are due to the difference in quality. This is understandable because the good quality is produced by good production process which is well executed and vice versa, the quality of the production becomes less good if the farming is not done well (Soekartawi, 2006).

Research from Nigeria case study found that fertilizer use in Nigeria is not as low as conventional belief suggests and locations in close proximity to key political figures tend to have better access to fertilizer. Yield response to (and profitability of) applied nitrogen for rice in Nigeria varies significantly across different agro ecological conditions and over time. When the full cost of fertilizer acquisition is taken into consideration, the profitability of nitrogen application falls significantly, remaining profitable for a relatively small subset of rice farmers. While observed mean nitrogen 
application rates for rice tend to lie below the economically optimal levels for farmers with high marginal physical product of applied nitrogen, we find mean observed use rates higher than expected profit maximizing rates for farmers with poor yield response to applied nitrogen. Reducing transportation and other costs associated with fertilizer acquisition is likely to significantly increase the profitability and use of nitrogen among Nigerian rice farmers (Saweda, 2014).

Another research that subsidies have been known to encourage fertilizer use among farmers. This paper examined the factors influencing rice farmer participate on in the government's fertilizer subsidy program. Data was collected through the aid of a well - structured questionnaire from 263 rice farmers. Descriptive and Logistic regression analysis were used to analyze the data. Statistical mean differences were found in age, household size, years of farming experience, farm size, output and total annual income between participants and non-participants. In addition, participation was significantly and positively influenced by marital status, household headship, membership of farmer association/groups, motorcycle ownership, mobile phone ownership, access to credit and total farm size. The paper concludes that efforts should be geared towards encouraging membership of farmer groups, availability and timely distribution of subsidized fertilizer and the establishment of more redemption centers (Hameed, 2017).

This study has explained the central importance of understanding the factors affecting to fertilizer demand in the paddy sector in Sri Lanka for exploring the possibility to total removal of fertilizer subsidy and substitutability of chemical fertilizer from organic fertilizer. The study used the secondary panel data gathered by the Department of Agriculture and Department of Census and Statistics for the period of 1990-2011 to estimate the input demand function for paddy cultivation sector. The most obvious finding to emerge from this study is that the factors such as price of fertilizer, price of seed paddy, price of labour, quantity of paddy output, cost of materials, cost of pest management, provision of the fertilizer subsidy, and commercial paddy cultivation have a significant impact on the demand for fertilizer. The study further found that the demand for fertilizer is relatively inelastic to the price of fertilizer, price of seed paddy, and the price of labour however; the price of seed paddy has a greater impact in sustaining paddy production in Sri Lanka than the fertilizer subsidy (Rodrigo, 2015).

This paper analysis the change in fertilizer subsidy policy in Sri Lanka with a view to understand its impact on national rice production, demand/supply of inputs, farm profit and government budget. In addition, cost effectiveness of the fertilizer subsidy is evaluated in terms of transfer inefficiency. Demand supply equilibrium model along with input markets is employed to obtain the results. The results indicate, complete fertilizer subsidy reduction would reduce rice production by around $4 \%$, while a $36 \%$ decline in the fertilizer demand for paddy cultivation. Although, the subsidy cut reduces the enormous government burden, farmers are unfavorably affected by $40 \%$ reduction of farm profit. Moreover, fertilizer subsidy would cause government to spend Srilangka Rupees (SLRs.) 1.38-1.91 to increase farm profit by one rupee. Meanwhile, a $3 \%$ decline of paddy production and a $14.5 \%$ increase in the rice price is expected with the proposed cash transfer policy (Wijetunga, Saito, 2017).

The research above discussed that the main factor that have a positive influence on fertilizer subsidy by the government or any sectors is cost production of rice farming, including price and the amount use fertilizer by each farmers. 


\section{RESEARCH METHOD}

This research conducted in Gorontalo City, Gorontalo Province. The research time from September to October 2017. The location of this study was chosen because generally the farmers in the location mostly get the subsidized fertilizer according to the data in RDKK in Gorontalo City.

Research was designed as a survey study. The data used in research that is primary data and secondary data. Primary data was obtained from interviews and fizzy excision by farmers of rice field farmer respondents in Gorontalo City. And secondary data is obtained from official reports from relevant agencies in this case such as Gorontalo Central Bureau of Statistics (BPS), and other agencies that can assist in providing data.

The population in this study selected by several sub-districts, such as South City Sub District, Middle City Sub District, West City Sub District, and Sipatana Subdistrict in Gorontalo City which determined by purposive sampling technique or intentionally because the five sub-districts had conducted preliminary survey so it was feasible defined as the research area. The total population in the five districts is 1,766 people.

The farmer respondents in this research done by completely random sampling with total population is 1,766 farmers. The way to get a representative sample is by random sampling process. In this process, each member of the population has the same opportunity or opportunity to be elected as a sample member (Spiegel and Stephens, 2004). In relation to the sample size, Slovin proposed a formula for determining the size of the sample, thus the samples taken as many as 95 respondents from 1,766 people as rice farmers in Gorontalo City.

Data analysis method used in this research is descriptive analysis method that is explained in detail about distribution of subsidized fertilizer in Gorontalo City. Furthermore, to know the effect of distribution of subsidized fertilizer to increase rice production used multiple linear regressions, with the following formula:

$$
\mathbf{Y}=\mathbf{a}+\mathbf{b}_{1} \mathbf{X}_{1}+\mathbf{b}_{2} \mathbf{X}_{2}+\mathbf{b}_{3} \mathbf{X}_{3}
$$

Where:

$\mathrm{Y} \quad=$ The increase of rice production

$\mathrm{X}_{1} \quad=$ Right price

$\mathrm{X}_{2} \quad=$ Right amount

$\mathrm{X}_{3} \quad=$ Right time

a $\quad=$ Constanta

b $\quad=$ Regression coefficient

\section{Variable definition}

1. Right price is the price of subsidized fertilizer purchased by farmers in accordance with the Highest Retail Price (HET).

2. The exact amount is the amount of subsidized fertilizer the farmer / farmer group receives based on the amount listed in the Group's Definitive Needs Plan (RDKK).

3. Right time is the farmer/farmer group at the time of fertilization on time and not beyond the period of fertilization.

4. Right type is farmer / farmer group buying fertilizer in accordance with the type of fertilizer that has been recommended by the government.

5. Right place is the farmer / farmer group buying the official retailer dikios fertilizer that has been determined by the distributor. 
6. Precise quality is the farmers / farmer groups using the guaranteed fertilizer according to the quality listed in the packaging / sack.

7. Production is an activity to increase the value added of an object or create a new object so that it is more useful in meeting the needs, in units ( $\mathrm{Rp}) /$ harvest in Gorontalo City.

8. Land area is the area of land owned or planted with rice paddy in Gorontalo City.

9. Labor is a person who performs work activities, so that the achievement of the business undertaken. Calculated in men equivalent working days (HKSP).

10. Capital is the costs incurred by rice farmers in Gorontalo City during the production process, in units $(\mathrm{Rp}) /$ harvest.

\section{RESULT AND DISCUSSION}

\section{Distribution of subsidized fertilizer flow in Gorontalo City}

The Ministry of Trade and the Ministry of Agriculture of the Republic of Indonesia have regulated the distribution system of subsidized fertilizer in Indonesia. Arrangement of distribution system of subsidized fertilizer in the hope that farmers get fertilizer based on the principle of six precisely i.e. the right price, right quantity, right time, right place, right type and quality.

In Gorontalo Province there are two producers of subsidized fertilizer namely PT Pupuk Kaltim as Urea fertilizer producer and PT Petrokimia Gresik as fertilizer producer of NPK Phonska, SP36, ZA and Petroganik. In distributing subsidized fertilizer, fertilizer producers appoint distributor companies as subsidized fertilizer distributors to authorized retailers. Distribution of subsidized fertilizer in Gorontalo city through several stages starting from line I up to line IV before finally reaching to farmers, where Line I is fertilizer warehouse in company, Line II that fertilizer warehouse is in port, Line III fertilizer warehouse is in Province or Regency and Line IV is in the authorized reseller warehouse. Line I to Line III is the responsibility of the manufacturer and Line IV is the responsibility of the retailer. In Gorontalo city there are 2 (two) fertilizer distributors namely PT. Indonesian Trade Company (PT PPI) and Indonesian Trade Cooperative (KPI), and 5 (five) authorized retailers which are distributing subsidized fertilizer namely Kios Tani Lestari, Anugerah Tani Kiosk, Saprodi Tani Kiosk, Kiosk Cahaya Tani and Kios Bunga Tani. PT. PPI is responsible for distributing NPK, SP36 and ZA fertilizers while KPI is responsible for the distribution of Urea fertilizer

\section{Classical assumption test}

\section{Normality data test}

The residual normality test purpose to test whether in the regression model, the dependent variable and the independent variable both have a normal distribution or not, a good regression model has normal or near-normal residual distributions. The Normal Probability Plot method comparing the cumulative distribution of the actual data with the cumulative distribution of the normal distribution, the Normal Probability Results Plot is presented in Figure 1 below can also identify the normality test: 


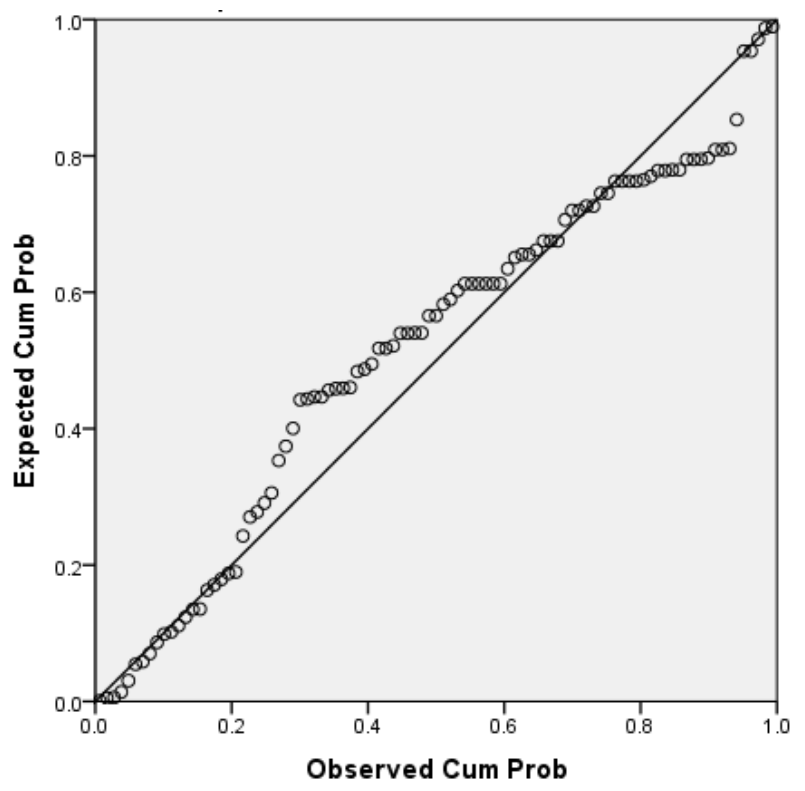

Figure1. Plot distribution in normality data test

Based on figure above showed that the data (point) spreads around the diagonal line and follows the direction of the diagonal line. By following the basic decisionmaking above, it is concluded that the data in this regression model meets the assumption of data normality.

\section{Multicollinearity test}

Multicollinearity test is purpose to determine the existence of a definite linear relationship between some or all of the independent variables describing the regression model. A good regression model should not be correlated between independent variables.

To know the presence of multicollinearity can also be seen on Tolerance and VIF (Variance Inflation Factor) value, that is: if tolerance value $>0.10$ and VIF $<10$, hence can be interpreted that there is no multicollinearity in the research. If tolerance values $<0.10$ and $\mathrm{VIF}>10$, then it can be interpreted that there is interference multicollinearity in this research. The result of multicollinearity test can be seen in table below:

Table 1.Multicollinearity result

\begin{tabular}{ccc}
\hline \multirow{2}{*}{ Variable } & \multicolumn{2}{c}{ Collinearity Statistics } \\
\cline { 2 - 3 } & Tolerance & VIF \\
\hline X1 & .326 & 3.067 \\
X2 & .474 & 2.111 \\
X3 & .319 & 3.135 \\
\hline
\end{tabular}

Table 1 showed that there is no multicollinearity regression model because VIF independent variable $<10$, that is variable of program policy equal to 0,326 , the right tolerancevariable value of the amount of 0.474 , and the time variable of 0.319 , VIF independent variable $<10$, is the right variable price of 3.067 , the right variable amount of 2.111, and time 3.135, soin this research no multicollinearity in regression.

\section{Statistical test result}

$\mathrm{R}^{2}$ test is used to know the influence of independent variable to dependent variable in this research the influence of right price, right amount, and right time to 
increase rice production in Gorontalo City is known from the coefficient of determination $\left(\mathrm{R}^{2}\right)$ as follow:

Table 2. Coefficient of determination test result $\left(\mathrm{R}^{2}\right)$

\begin{tabular}{lcccc}
\hline Model & R & R Square & Adjusted R Square & $\begin{array}{c}\text { Std. Error of the } \\
\text { Estimate }\end{array}$ \\
\hline 1 & $.929^{\mathrm{a}}$ & .863 & .859 & 1.68330 \\
\hline
\end{tabular}

a. Predictors: (Constant), X3, X2, X1

b. Dependent Variable: Y

Based on the table above, the value of determination $\mathrm{R}^{2}$ is 0,859 means that the data indicate that the influence of right price, right amount, and right time to increase rice production in Gorontalo city equal to 85.9 percent, while the rest is 14.1 percent influenced by other factors that excluded in this research.

( $F$ test) together simultaneously between independent variables in this case areright price $\left(\mathrm{X}_{1}\right)$, right amount $\left(\mathrm{X}_{2}\right)$, right time $\left(\mathrm{X}_{3}\right)$ and rice production $(\mathrm{Y})$, Result of analysis together by result analysis with SPSS program version 20 obtained the following results:

Tabel 3. Simultaneous test (F-test)

\begin{tabular}{llrrrrr}
\hline Model & & $\begin{array}{c}\text { Sum of } \\
\text { Squares }\end{array}$ & df & Mean Square & \multicolumn{1}{c}{ F } & \multicolumn{1}{c}{ Sig. } \\
\hline 1 & Regression & 1629.651 & 3 & 543.217 & 191.713 & $.000^{\mathrm{b}}$ \\
& Residual & 257.848 & 91 & 2.833 & & \\
& Total & 1887.499 & 94 & & & \\
\hline
\end{tabular}

Based on the result of analysis in Table 4 obtained the value of F-count of 191,713 F-count between right price $\left(\mathrm{X}_{1}\right)$, right amount $\left(\mathrm{X}_{2}\right)$, right time $\left(\mathrm{X}_{3}\right)$ and rice production (Y) in Gorontalo City.

After it is known that there is simultaneously influence then tested partially from independent variable (right price, right amount, and right time) to dependent variable of rice production at Gorontalo City. Sarwono (2007), said that positive or negative results only show the direction rather than indicating the number.

Table 4. Analysis regression model

\begin{tabular}{llrrrrr}
\hline & & \multicolumn{2}{c}{$\begin{array}{c}\text { Unstandardized } \\
\text { Coefficients }\end{array}$} & $\begin{array}{c}\text { Standardized } \\
\text { Coefficients }\end{array}$ & & \\
\cline { 3 - 5 } Model & & \multicolumn{1}{c}{ B } & Std. Error & Beta & \multicolumn{1}{c}{ T } & Sig. \\
\hline 1 & (Constant) & -3.318 & 1.741 & & -1.906 & .060 \\
& X1 & .198 & .060 & .224 & 3.301 & .001 \\
& X2 & .236 & .096 & .138 & 2.457 & .016 \\
& X3 & .464 & .050 & .634 & 9.248 & .000 \\
\hline
\end{tabular}

Based on the previous research, where factors such as price of fertilizer, price of seed paddy, price of labor, quantity of paddy output, cost of materials, cost of pest management, provision of fertilizer subsidy, and commercial paddy cultivation have a significant on the demand fertilizer. The price elasticity relatively inelastic to the price of fertilizer and this is acceptable that given lack of close to substitutes to chemical fertilizer. The price of paddy seed has a greater significant effect to paddy production in Srilanka because the increasing of seed price will attempt farmers to overuse fertilizer and it will cause limit farmers to sustain their production. Based on the subsidy fertilizer 
has the impact to the fertilizer market, where if there is no continuity of fertilizer subsidy it will make farmers to use the fertilizer that produce from market (Rodrigo, 2015).

Based on the reviews from other research we can separate to the discussion above closely to the fertilizer price and the amount of fertilizer use in Gorontalo city to increase the rice production below:

\section{The effect of right price to increased rice production}

Based on a positive analysis of production elasticity indicates that the exact price is in a rational area. Based on the value of t-test obtained the exact input price of 3.301 which the value of the exact significance of the price $(0.001)$ is smaller than the probability value of 0.05 . Therefore, it can be concluded that the exact price has a significant effect on increasing rice production in Gorontalo City.

Coefficient $\mathrm{X}_{1}$ (Right Price) $=0.198$. The regression coefficient of variable at the right price indicates that every change in the exact variable price is 1 unit, then the production of paddy in Gorontalo City will experience change of 0.198 unit with the condition of right variable amount and on time constant (cateris paribus),

In this research, the price of subsidized fertilizer is in accordance with the highest retail price (HET) stated in the Regulation of Minister of Agriculture No. 69 / Permentan / SR, 310/12/2012, HET for fertilizer is still needed by the farmers of respondents, to make it easier for farmers in purchase of fertilizer for rice production process. The exact price in this research has a significant effect on the increase of paddy rice production, it means that when fertilizer price is lower than farmers are more easily reach fertilizer price.

\section{The effect of right amount to increased rice production}

Based on a positive analysis of production elasticity indicates that the right Amount is in a rational area. Based on the value of t-test is obtained the right input amount of 2.457 that significance value of right amount (0.016) smaller than the probability value of 0.05 a So it can be concluded that the exact number of significant effect on increasing rice production in Gorontalo City.

Coefficient $\mathrm{X}_{2}$ (Right Amount) $=0.236$. The right regression coefficient of variable indicates that each change in exact variable amount of 1 unit, then the production of rice in Gorontalo City will experience a change of 0.236 unity with the provisions of the exact variable price and time in a constant (cateris paribus),

Based on the results of research the use of the number of subsidized fertilizer by farmers of respondents in the city of Gorontalo is in accordance with recommended doses, but in this study, subsidized fertilizer limited one of phonska fertilizer. In addition, farmers' respondents do not switch to non-subsidized fertilizer, so farmers only use urea fertilizer, without switch to non-subsidized fertilizer caused by limited farmer capital and the price of non-subsidized fertilizer is more expensive. For every ton of rice produced, it takes about $14.4 \mathrm{~kg} \mathrm{~N}, 2.6 \mathrm{~kg} \mathrm{P}$ and $14.5 \mathrm{~kg} \mathrm{~K} / \mathrm{ha}$, which can be obtained by plant of soil, irrigation water, crop residues or from fertilizers (organic or inorganic) added. The higher the results obtained the higher the amount of nutrients needed and vice versa. Therefore, the exact number in this study significantly affects the increase in production.

\section{The effect of right time to increased rice production}

Based on a positive analysis of elasticity of production indicates that time is in a rational area. Based on the value of t-test, the timely significance of the value of 0.248 is 
obtained. The value of the time significance $(0,000)$ is smaller than the probability value of 0.05 . Therefore, it can be concluded that time significant effect on increasing rice production in Gorontalo City.

Coefficient $\mathrm{X}_{3}$ (Right Time) $=0.464$. The time variable regression coefficient indicates that every change in the timely variable is 1 unit, then the rice production in Gorontalo City will experience a change of 0.464 unity with the provision of the exact variable price and the exact amount in a constant (cateris paribus).

This is caused by the use of effective and efficient fertilizer, so the quality of soil as rice planting medium will provide the substances needed by plants to produce optimal rice production. At the research location of farmers respondents using fertilizer has been effective and efficient, because most farmers do fertilization as much as 2 times and some farmers do fertilization as much as 3 times. In addition to the application of proper fertilization, retailers order subsidized fertilizer according to the needs of farmers and fertilizer ordering done according to the growing season,

Based on the research in the field, the effect of subsidized fertilizer distribution on the increase of production has a positive and real effect seen from the right price, the right number and right time simultaneously. While the partial distribution of subsidized fertilizers based on the exact price and on time has a positive and real effect on the increase of rice production (HET) for urea fertilizer of Rp 1,800 per kilogram and phonska fertilizer of $\mathrm{Rp} 2,300$ per kilogram, easy to be reached by respondent farmers, then from the timeliness in distribution of subsidized fertilizer and application time fertilizer on rice crop has been efficient. While seen from the right number of distribution of subsidized fertilizer has a positive and not real effect, this is due to the scarcity of phonska fertilizer. This is in line with the opinion Primantoro (2005: 24), which states that phonska fertilizer as one facts or production that has a large contribution to farming, The size of the production of farming, among others, is influenced by phonska fertilizer used.

\section{CONCLUSION AND RECCOMENDATION}

\section{Conclusions}

In Gorontalo City there are two fertilizer distributors namely PT. Indonesian Trade Company (PT PPI) and Indonesian Trade Cooperative (KPI), and 5 authorized retailers which are distributing subsidized fertilizer namely Kios Tani Lestari, Anugerah Tani Kios, Saprodi Tani Kios, Cahaya Tani Kios and Bunga Tani Kios. PT. PPI is responsible for distributing NPK, SP36 and ZA fertilizers while KPI is responsible for the distribution of Urea fertilizer.

Distribution of subsidized fertilizer on rice farming simultaneously have a positive and real effect on increasing rice production. While the distribution of subsidized fertilizer on rice farming partially that has a positive and tangible effect that is precise price, exact amount, and timely to increase rice production.

\section{Recommendation}

The subsidized fertilizer program needs to be continued and need to be accompanied by other programs in order to improve the empowerment and welfare of farmers. There is a need for additional authorized retailers stalls in each Sub District to make farmers easier to cultivate and reduce transportation costs.

There needs to be further research on the effect of the distribution of subsidized fertilizer to increase rice production in Gorontalo City, which is not found by the authors. 


\section{REFERENCES}

Buchari, Alma. (2007), “Manajemen Pemasaran \& Pemasaran Jasa”. Bandung: CV. Alfabeta

Dinas Pertanian, (2017). Provinsi Gorontalo, Gorontalo

DKPP, 2017.Kota Gorontalo. Gorontalo

Gujarati, Damodaar N, (2006), "Basic Econometrics, Fourd Edition, McGraw Hill Co

Khairunisya, (2009), "Efektifitas Penyaluran Pupuk Bersubsidi Bagi Petani Padi Di Kabupaten Lampung Tengah” (Studi Kasus : Lini IV Kecamatan Trimurjo).

Ogheneruemu, OBI-EGBEDI. Abdul Hameed, BANKOLE Olaide. (2017). Determinants of Participation in Fertilizer Subsidy Programme Among Rice Farmers in Ogun State, Nigeria. Journal of Development and Agriculturan Economics Vol. 9 (6), pp, 162-167, June 2017

Permenpan, (2016). Jakarta

Rini Desi Puspo. (2006). Analisis Pengaruh Pupuk Bersubsidi Terhadap Kinerja Industri Pupuk di Indonesia. Tesis.Fakultas Ekonomi Dan Manajemen Institut Pertanian Bogor. Bogor.

Rodrigo, Chatura. Abeysekera, lakmal. (2015). Why The Fertilizer Subsidy Should Be Removed: key Factors That Actually Derive The Fertilizer Demand in Paddy Sector of Sri Lanka. Sri Lanka Journal of Economic Research Volume 3 (2) December 2015: 71-98. Sri Lanka Forum of University Economists

Saweda O, Lenis, barret, Christopher B, and Sheahan Meghan. (2014). Understanding Fertilizer For Rice Production Across Nigeria's Diverse Agro Ecological Conditions. http//www.worldbank.org/. Annual Bank Conference onAfrica,June 23 th $-24^{\text {th }} 2014$

Soekartawi. (2006). Analisis Usahatani. Penerbit Universitas Indonesia, Jakarta.

Sudjana. (2002). Metode Statistika. Penerbit PT Tarsito. Bandung

Sugiyono. (2014). Metode Penelitian Kuantitatif, Kualitatif dan R\&D. Cetakan ketujuhbelas. Penebar ALFABETA,CV. Bandung.

Wijetunga, Chatura. Saito, Katsuhiro. (2017) Evaluating The Fertilizer Subsidy Reforms in The Rice Production Sector in Sri Lanka: A Simulation Analysis. Advances In Management \& Applied Economics, Vol. 7, No. 1, 2017, 31-51

Winardi. (2005). "Strategi Pemasaran” (Marketing Strategi). Bandung: Mandar Maju 